\title{
Transient Myopia after Hyperbaric Oxygen Therapy: CaseReport
}

\author{
Şeyma Gülcenur Özturan ${ }^{1 *}$, Gamze Maden ${ }^{1}$, Akın Çakır ${ }^{1}$, Mehmet Egemen Karataş², Alper Halil Bayat ${ }^{1}$ and \\ Mustafa Nuri Elçioğlu ${ }^{1}$ \\ ${ }^{1}$ Department of Ophthalmology, Okmeydani Training and Research Hospital, Turkey \\ ${ }^{2}$ Department of Ophthalmology, Sisli Hamidiye Etfal Training and Research Hospital, Turkey
}

Submission: May 28, 2018; Published: June 07, 2018

*Corresponding author: Seyma Gulcenur Ozturan, Department of Ophthalmology, Okmeydani Training and Research Hospital, Istanbul, Turkey, Tel: +90-535-9608011; Email: gulcenurozturan@gmail.com

Abstract

Hyperbaric Oxygen Therapy (HBO) is a therapy which consisting of more than 95\% oxygen at 2-3 atmospheres. It has ocular side effects such as transient myopia, nuclear cataract, thinning in corneal endothelium, defect in lens epithelium, construction in retinal vessels. So it is very important to perform detailed ophthalmologic examination of patients after HBO. The patient presented to emphasize the ocular side effects of HBO.

Keywords: Hyperbaric oxygen; Myopia; Refractive change

\section{Introduction}

Hyperbaric Oxygen Therapy (HBO) is a therapy which consisting of more than $95 \%$ oxygen at 2-3 atmospheres [1]. It is a commonly used treatment in lots of diseases, including osteoradionecrosis, diabetic ulcers, decompression sickness, anaerobic infections $[2,3]$.

HBO has side effects such as middle ear, teeth, pulmonary barotrauma [4]. Its ocular side effects are transient myopia, nuclear cataract, thinning in corneal endothelium, defect in lens epithelium, construction in retinal vessels [5]. In our case report, we would like to explain transient myopia after the HBO.

\section{Case Presentation}

A 62-year-old male patient was admitted to the ophthalmology clinic with complaints of low vision in both eyes with his own eye-glass for one week. He said, he treated with HBO because of sudden hearing loss and his vision was lower after HBO.

The vision at the arrival of the patient was 0.5 snellen equivalent (SE) in right eye and 0.7 (SE) in left eye with his eye-glass. His eye-glass diopter values were +4.75 on the right eye and +3.50 (on the left eye. Anterior and posterior segment examination was bilaterally natural with biomicroscopic examination. Intraocular pressure (IOP) was $13 \mathrm{mmHg}$ on the right eye and $15 \mathrm{mHg}$ on the left eye. Patient's refractive state was assessed with an auto refractometer. And diopter measurements were +3.50 on the right eye, +3.00 on the left eye. We added a plus sphere power for find the best visual acuity. And his vision was bilaterally 1.0 (SE) with +3.50 glass on the right eye and +3.00 on the left eye. So we realized that he had significant myopic shift. According to our thoughts, his complaints were due to myopic shift which can be seen after HBO. Patient had headache with his old eye glass so we prescribed a new glass for the patient but we explained that it will be transient eye glass.

\section{Discussion}

In HBO, patients breath oxygen at high pressure, so oxygen's transfer -from blood to tissue- increases. Oxygen and nitrogen radicals occur with high oxygen pressure. They activate transduction signals, growth factors and hormones. High oxygen stress also activate glutathione, thioredoxin, pyrimidine nucleotides, signal mechanisms between cells, antioxidants and protector mechanisms. Local endothelial cells and progenitor cells are stimulated by high oxygen pressure and they cause angiogenesis. Neutrophils and vascular endothelial growth factors are stimulated by beta integrin, and they increase reperfusion, neovascularization in ischemic tissues [4,5]. So HBO uses in diabetes or non-diabetes wounds, non-healing tissues, carbon monoxide intoxication, sudden hear loss, central retinal artery occlusion, osteonecrosis, brain abscess $[2,3]$. 
One of the ocular side effect of HBO is myopic shift. There is no changes in axial length, corneal refractive index, anterior chamber distance or corneal thickness after HBO. Evanger et al. [3] study findings suggested that the myopic shift seen in patients treated with $\mathrm{HBO}$ is only related with changes in the crystalline lens [3]. Molecular changes affect to lens proteins and they increase nuclear refractive index also decrease cortical refractive index and it increase insoluble lens proteins. In addition oxidative stress cause aggregation of proteins in lens nucleus. All can cause myopic shift [2,6,7]. Even 3 diopter myopic changes has been reported [7]. It is the most in 2-4 days after HBO and it returns to original refractive state after 8-10 weeks [5]. It doesn't related with first refractive index, age or gender [8].

As a result, HBO is a commonly used treatment in many human diseases and has lots of ocular side effects. So we should perform detailed ophthalmologic examination to patients who treated with HBO.

\section{References}

1. Fiedelius HC, Jansen EC, Thorn J (2002) Refractive change during hyperbaric oxygen therapy. A clinical trial including ultrasound oculometry. Acta Ophthalmol Scand 80(2):188-190.

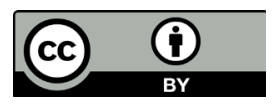

This work is licensed under Creative Commons Attribution 4.0 License DOI: 10.19080/JOJCS.2018.07.555710
2. Evanger K, Haugen OH, Aanderud L, Thorsen E, Pierscionek BK (2006) Hypermetropia-succeeded myopia after hyperbaric oxygen therapy. Optom Vis Sci 83(3): 195-198.

3. Evanger K, Vaagbo G, Thorsen E, Haugen OH (2011) Phakic and pseudophakic eyes in patients during hyperbaric oxygen therapy. Optom Vis Sci 88(6): 691-696.

4. Thom SR (2011) Hyperbaric Oxygen-its mechanism and efficacy. Plast Reconstr Surg 127 Suppl 1: 131S-141S.

5. Evanger K, Haugen OV, Irgens A, Aanderud L, Thorsen E (2004) Ocular refractive changes in patients receiving hyperbaric oxygen administered by oronasal mask or hood. Acta Ophthalmol Scand 82(4): 449-453.

6. Evanger K, Pierscionek BK, Vaagbø G, Thorsen E, Haugen OH (2015) Myopic Shift during Hyperbaric Oxygenation Attributed to Lens Index Changes. Optom Vis Sci 92(11): 1076-1084.

7. Bantseev V, Oriowo OM, Giblin FJ, Leverenz VR, Trevithick JR, et al. (2004) Effect of hyperbaric oxygen on guinea pig lens optical quality and on the refractive state of the eye. Exp Eye Res 78(5): 925-931.

8. Andrawus-Haddad F, Ben Zion I, Melamed Y, Garzozi H (2010) The rate of development of myopia during hyperbaric oxygen therapy. Harefuah 149(12): 773-766.

\section{Your next submission with Juniper Publishers will reach you the below assets}

- Quality Editorial service

- Swift Peer Review

- Reprints availability

- E-prints Service

- Manuscript Podcast for convenient understanding

- Global attainment for your research

- Manuscript accessibility in different formats

( Pdf, E-pub, Full Text, Audio)

- Unceasing customer service

Track the below URL for one-step submission https://juniperpublishers.com/online-submission.php 